\title{
CHARACTERIZATION OF STRUCTURAL MATERIALS BY SPHERICAL INDENTATION
}

\author{
KARAKTERIZACIJA STRUKTURNIH MATERIALOV PRI \\ SFERIČNEM VTISKOVANJU
}

\author{
Jaroslav Čech, Petr Haušild, Ondřej Kovářík \\ Czech Technical University, Faculty of Nuclear Sciences and Physical Engineering, Department of Materials, Trojanova 13, 120 00, \\ Prague 2, Czech Republic \\ jaroslav.cech@fjfi.cvut.cz
}

Prejem rokopisa - received: 2016-10-19; sprejem za objavo - accepted for publication: 2017-01-16

doi:10.17222/mit.2016.302

\begin{abstract}
Nano-indentation with spherical indenters is a method of mechanical properties characterization that could be used for the determination of stress-strain curves. A necessary condition for an evaluation of the results is an exact knowledge of the indenter shape. In this study, the shapes of two spherical indenters with a nominal radius of $20 \mu \mathrm{m}$ were investigated by atomic force microscopy and by indentation into materials with a known Young's modulus. It was found that the actual indenter differs from the ideal shape and it is affected by the crystallographic orientation of the diamond crystal. The effective radius determined from the indentation measurements depends on the material deformation characteristics and it was lower than the actual radius. The computed representative stress vs. representative strain curves of steel samples were significantly affected by the actual radii of the investigated indenters.

Keywords: nano-indentation, spherical indenter, actual indenter shape, representative stress, representative strain curves
\end{abstract}

Nanoindentacija s sferičnimi vtiskovalci je metoda karakterizacije mehanskih lastnosti, ki se lahko uporablja za ugotovitev napetostno-deformacijske krivulje. Pogoj za oceno rezultatov je točno določeno poznavanje stanja vtiskovalca. V študiji sta bili raziskovana dva sferična vtiskovalca z nominalnim radijem $20 \mu \mathrm{m}$, ki sta bila raziskovana $\mathrm{z}$ AFM in $\mathrm{z}$ vtiskovanjem v material z Youngovim modulom. Ugotovljeno je bilo, da se dotični vtiskovalec razlikuje od idealne oblike in, da nanj vpliva kristalografska orientacija diamantnega kristala. Efektivni radij, ugotovljen z meritvami vtiskovanja je odvisen od deformacije karakteristik materiala in je bil nižji od dejanskega radija. Izračunane reprezentativne napetostne krivulje jeklenih vzorcev so bile občutno pod vplivom dejanskih radijev preiskovanih vtiskovalcev.

Ključne besede: nanoindentacija, sferični vtiskovalec, dejanska oblika vtiskovalca, reprezentativna napetost, reprezentativna napetostna krivulja

\section{INTRODUCTION}

Nano-indentation is an effective method for the characterization of mechanical properties for very small volumes of material. It is advantageously applied when standard tests (e.g., tensile, fracture toughness tests) cannot be used. It can be employed to characterize thin films, welds or individual phases of a multi-phase material.

Sharp indenters (such as the Berkovich three-sided pyramid) are the most frequently used due to the simplicity of the data interpretation. On the other hand, they do not provide any information about the evolution of the elastic and plastic stress-strain field under the indenter. In spherical indentation, the stress and strain progressively increase with the penetration depth and thus the stress-strain curves of the materials can be determined.

Several models are used for a description of the elastic-plastic stress-strain field under the indenter. At the beginning of the indentation process, only elastic deformation occurs and Hertz theory can be applied. ${ }^{1}$ With increasing penetration depth, the plastic zone starts to evolve under the surface below the indenter and it spreads to the surface. ${ }^{2}$ When the plastic zone is fully developed, the ratio of hardness to yield strength stabilizes at an approximate value $H / \sigma_{y}=3 .{ }^{3}$ This ratio expresses the restriction of plastic deformation under the indenter compared to the tensile tests. Several models make it possible to evaluate stress-strain curves in whole range of deformations. ${ }^{4}$ Methods determining the yield strength, strain hardening exponent and other mechanical characteristics do exist; however, several problems have to be considered when analyzing the experimental data.

The crucial factor is a knowledge of actual indenter shape. ${ }^{5-9}$ The real indenter does not match its ideal shape. Imperfections are created already during the indenter's fabrication and the indenter is progressively worn with usage. The shape and properties of the indenter also depend on the crystallographic orientation of the diamond crystal. ${ }^{10}$ The projected indenter area function $A_{\mathrm{p}}$ effectively corrects the imperfections of Berkovich, Vickers, or conical indenters. However, for the spherical indenters, the actual projected area is not frequently used as it cannot be directly related to the actual radius, giving a tangent at the contact. Instead, the effective radius of the indenter $R_{\text {eff }}$ can be used.

In this study, two diamond spherical indenters with the nominal radius $R=20 \mu \mathrm{m}$ were investigated. Their 


\section{J. ČECH et al.: CHARACTERIZATION OF STRUCTURAL MATERIALS BY SPHERICAL INDENTATION}

actual shape was determined by direct (atomic force microscopy) and indirect (indentation into materials with a known Young's modulus) methods and its effect on the stress-strain curves of structural materials was evaluated.

\section{MATERIALS AND METHODS}

Indentation tests were carried out on Anton Paar CSM NHT nano-indentation instrument. Two steel samples (hardness etalon $487 \mathrm{HV}$ from ball bearing carbon steel and bainitic JRQ steel used in the nuclear industry) were investigated by two spherical diamond indenters (denoted as indenter $\mathrm{A}$ and indenter B) with nominal radius $R=20 \mu \mathrm{m}$. Electrolytically polished samples were loaded in the regime with partial unloading (CMC mode) in the range of maximum force from $10 \mathrm{mN}$ to $500 \mathrm{mN}$. The whole indentation test consisted of 20 cycles with progressively increasing maximum force. The increase to the maximum force in the cycle takes $10 \mathrm{~s}$, holding at maximum force $5 \mathrm{~s}$, and unloading to $20 \%$ of maximum force $10 \mathrm{~s}$. Every unloading was analyzed using the Oliver-Pharr procedure. ${ }^{11}$

Since the shape of the indenter is not supposed to be ideal, the calibration procedure was performed for both indenters. For a contact depth $h_{\mathrm{c}}$ given by Equation (1): ${ }^{12}$

$$
h_{\mathrm{c}}=h_{\max }-0.75 \frac{P_{\max }}{S}
$$

the projected contact area $A_{\mathrm{p}}$ was determined according to Equation (2): ${ }^{12}$

$$
A_{\mathrm{p}}\left(h_{\mathrm{c}}\right)=\frac{\pi S^{2}}{4 E_{\mathrm{r}}^{2}}
$$

where the maximum penetration depth $h_{\max }$, maximum applied force in the cycle $P_{\max }$, and contact stiffness $S$ are obtained from the force-displacement curve. $E_{\mathrm{r}}$ stands for the reduced modulus, comprising elastic properties of the indenter and the sample in Equation (3): ${ }^{12}$

$$
\frac{1}{E_{\mathrm{r}}}=\frac{1-v_{\mathrm{s}}^{2}}{E_{\mathrm{s}}}+\frac{1-v_{i}^{2}}{E_{i}}
$$

The Young's modulus and Poisson's ratio of sample $E_{\mathrm{s}}$ and $v_{\mathrm{s}}$ were determined by independent ultrasound pulse-echo measurement, and $E_{i}$ and $v_{i}$ are the known Young's modulus and Poisson's ratio of the diamond indenter, respectively. The indenter effective radius can be obtained from the geometry of the system (relation between the projected contact area and the contact depth):

$$
R_{\text {eff }}=\frac{\frac{A_{\mathrm{p}}}{\pi}+h_{\mathrm{c}}^{2}}{2 h_{\mathrm{c}}}
$$

Representative stress $\sigma_{\text {repr }}$ vs. representative strain $\varepsilon_{\text {repr }}$ curves were determined using Tabor formulae in Equation $(5):^{3}$

$$
\sigma_{\text {repr }}=\frac{P_{\max }}{C \pi a^{2}}, \quad \varepsilon_{\text {repr }}=0.2 \frac{a}{R}
$$

where $C$ is a constraint factor $(C=3), a$ is the contact radius, and $R$ is the radius of the indenter (nominal or effective).

The tips of the spherical indenters were also examined by atomic force microscope AFM Park XE-100 with closed-loop z-piezo in tapping mode. An area of $20 \times 20 \mu^{2}$ was scanned with the resolution of $256 \times 256$ points. The data were corrected to the drift in slow scanning axis and the noise was filtered. The projected area $A_{\mathrm{p}}$ for the depths up to $2 \mu \mathrm{m}$ was estimated from AFM measurements as a surface of a planar cut through the indenter perpendicular to the load axis. From the measured $A_{\mathrm{p}}\left(h_{\mathrm{c}}\right)$ dependency, the actual radius of the indenters was computed using Equation (4).

\section{RESULTS AND DISCUSSION}

\subsection{Atomic force microscopy}

The topology of the indenters A and B and the maps of their local radius of curvature obtained from the analysis of AFM data are shown in Figure 1. The local radius of curvature is defined as a radius of the sphere interpolated in the circular neighborhood $(1 \mu \mathrm{m}$ in radius) of the particular point on the indenter surface. Comparing the topology of both indenters, it can be seen that the indenter B is more irregular than the indenter A. The differences are also visible on the maps of local radius of curvature, where the local radius of curvature of indenter A at the apex is higher than for indenter B and it reaches a higher value than the stated $20 \mu \mathrm{m}$.

For the data analysis, and also for the fabrication of the diamond indenters, it is very important to know its crystallographic orientation. The investigated indenters were produced with the loading axis parallel to the direction [100] of the diamond crystal. The crystallographic orientation has a significant effect on the indenter actual
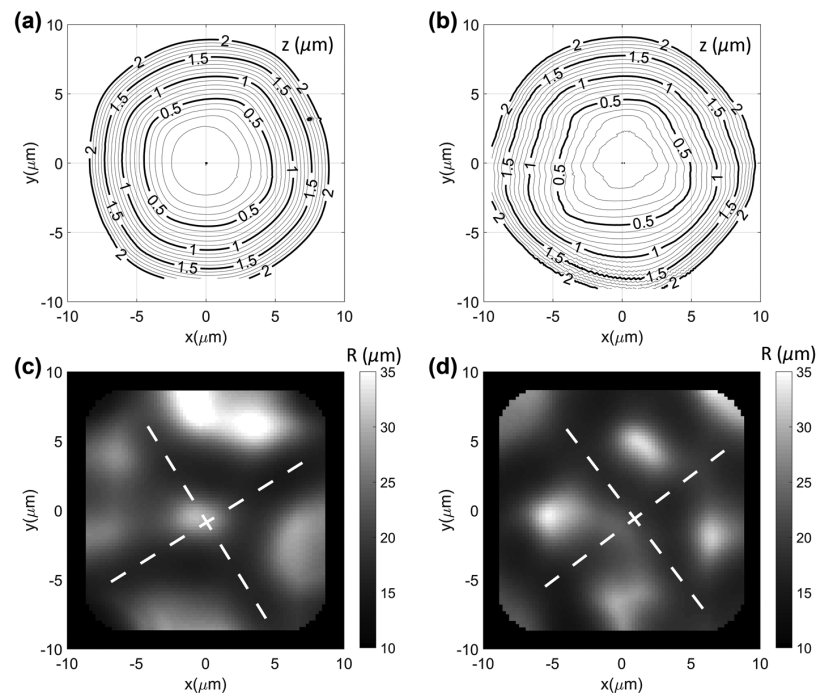

Figure 1: AFM images of: a) the topology of indenters A and b) indenter B, c) local radius of curvature of indenters A and d) B with shown axes of the four-fold symmetry (dashed lines) 
shape and it can introduce deviation from its nominal spherical shape. As the diamond crystal is anisotropic, it is worn and grinded more easily in the softer directions. The four-fold symmetry of the diamond crystal is clearly visible in the figures of the local radius of curvature (Figure 1c and 1d).

The actual radii estimated from Equation (4) are shown in Figure 2. The radius determined by AFM decreases with depth for both investigated indenters. The decrease is more abrupt for indenter A (from approximately $R=30 \mu \mathrm{m}$ to $R=22 \mu \mathrm{m}$ at a depth $h=100 \mathrm{~nm}$ and $h=500 \mathrm{~nm}$, respectively). For greater depths, the radius of indenter $\mathrm{A}$ stabilizes at a nominal value of $R=20 \mu \mathrm{m}$. The radius of indenter B decreases only slightly from $R=24 \mu \mathrm{m}$ at a depth $200 \mathrm{~nm}$ to $R=23 \mu \mathrm{m}$ at a depth $500 \mathrm{~nm}$. For depths $h>400 \mathrm{~nm}$ it is higher than the radius of indenter $\mathrm{A}$ and it reaches a constant value of nearly $23 \mu \mathrm{m}$, far more than the nominal value of $20 \mu \mathrm{m}$.

\subsection{Indentation}

Evolution of the effective radius determined from indentation measurements on steel samples at low penetration depths shows a different trend compared with AFM results. The effective radius increases from a very low value of about $10 \mu \mathrm{m}$ and it reaches its maximum at a depth approximately $h=200 \mathrm{~nm}$. These low values of effective radius result from the uneven contact between the indenter and the surface of the sample. After electrolytic polishing, the surface of steel sample is wavy, as schematically shown in Figure 3. The indenter touches the local surface asperities and thus the actual contact area for a given penetration depth is not spherical, but it is irregular and smaller than the theoretical one. According to Equation (4) the final effective radius is subsequently smaller than the actual radius of the indenter.

The maximum effective radius from the indentation measurements differs for both investigated indenters and materials. Higher values were obtained by indenter A than by indenter B, similar to the AFM measurements. For greater depths the evolution of the effective radius follows the trend of the AFM measurements. The radius

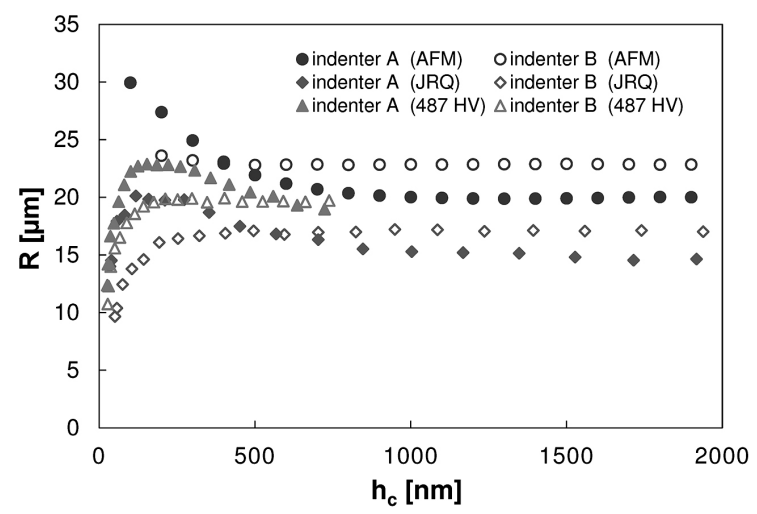

Figure 2: Radius of spherical indenters with nominal radius $R=20 \mu \mathrm{m}$ obtained by AFM and indentation measurements

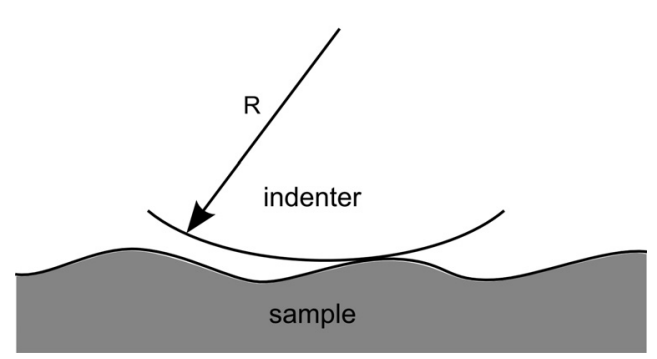

Figure 3: Schematic sketch of contact between spherical indenter and surface asperities ${ }^{13}$

of indenter A decreases with depth and it is lower than the radius of indenter $B$ from depths of about $600 \mathrm{~nm}$. The effective radius of indenter $\mathrm{B}$ is rather constant. However, the effective radii could not be compared for higher penetration depths since high hardness of etalon $487 \mathrm{HV}$ and the maximum possible applied force $(500 \mathrm{mN})$ limit the maximum penetration depth into the $487 \mathrm{HV}$ sample to approximately $1 \mu \mathrm{m}$.

The differences in the effective radius estimated from indentation into JRQ steel and etalon $487 \mathrm{HV}$ could be explained by the difference of their elastic-plastic properties. It is well known that the contact area (which is used for a determination of effective radius) depends on the actual indenter shape and the material deformation characteristics. ${ }^{14}$ The effects of pile-up or sink-in can introduce the error in the determination of contact area by as much as $60 \% .{ }^{15}$ The effective radii measured by indentations on investigated samples are lower than the radii from the AFM. More significant difference is for JRQ steel, which is probably caused by higher strain hardening exponent.

Representative stress vs. representative strain curves were evaluated according to Equation (5) and they are presented in Figure 4. Each material was investigated by both indenters. The results considering nominal radius $R=20 \mu \mathrm{m}$ and effective radius $R_{\text {eff }}$ obtained from the indentation into the corresponding material were compared. To avoid the problems with the transition from the elastic to the plastic region and the errors arising from the uncertainty of geometry of contact at low penetration depths, the cycles with low maximum load were excluded from the analysis.

As the nominal radius is higher than the effective radius, flow curves of JRQ steel using $R=20 \mu \mathrm{m}$ are lower than the curves obtained with $R_{\text {eff }}$ (Figure $4 a$ ). The curves based on nominal radius significantly differ for both indenters, especially for lower deformations (i.e., low penetration depths). Moreover, stress obtained with indenter A using nominal radius decreases with increasing deformation, which should not occur as the material is hardening. It is caused by an important difference between the nominal and the actual shape of indenter $\mathrm{A}$ at low depths (Figure 2). Using the effective radius, the flow curves obtained by both indenters are nearly equivalent. Small differences could result from using Equation (5) for evaluating representative deformation. The for- 


\section{J. ČECH et al.: CHARACTERIZATION OF STRUCTURAL MATERIALS BY SPHERICAL INDENTATION}
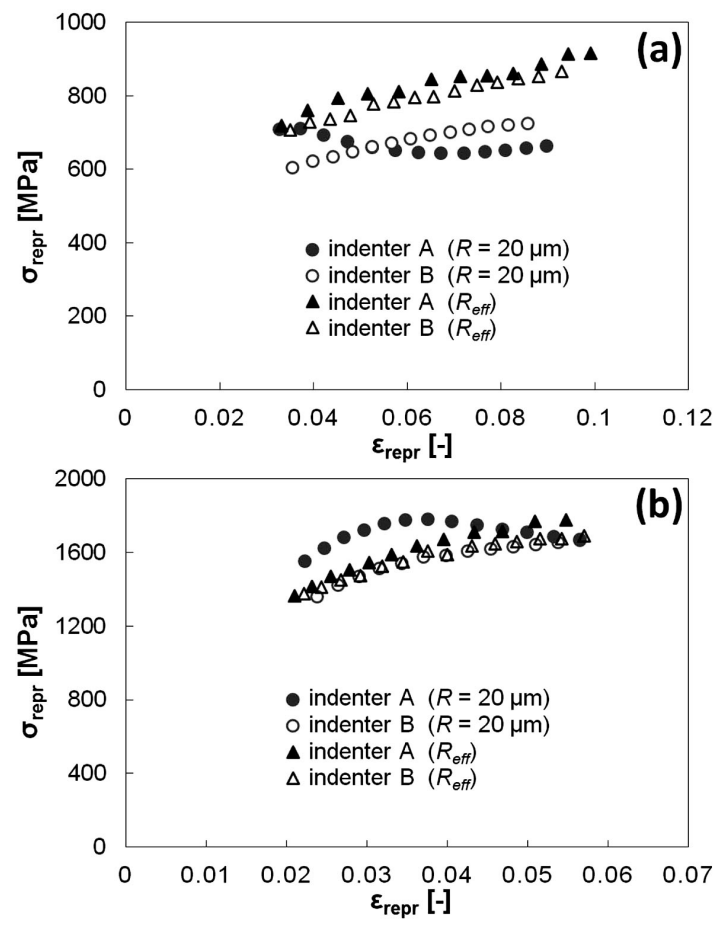

Figure 4: Representative stress vs. representative strain curves obtained using Tabor formulae: a) JRQ steel, b) hardness etalon $487 \mathrm{HV}$

mula for representative deformation is based on the ratio of contact and indenter radii $a / R$, which is valid for ideally spherical indenters. Actual deformation is given by the contact angle between the indenter and the sample surface. As the shape of the indenter is not ideally spherical, approximation of this angle by $a / R$ is not exactly valid and it could introduce small errors into the values of the representative deformation.

The decrease of the stress with strain was also observed for hardness etalon $487 \mathrm{HV}$ using indenter A and $R=20 \mu \mathrm{m}$. Nevertheless, the differences in flow curves, which results from using nominal and effective radius, are less significant than for JRQ steel. For indenter B, representative stress vs. representative strain curves are nearly identical as the effective radius for higher penetration depths reaches approximately its nominal value $R=20 \mu \mathrm{m}$.

\section{CONCLUSIONS}

The shapes of two diamond spherical indenters with nominal radius $R=20 \mu \mathrm{m}$ were investigated in this study. Their actual and effective radius was determined by AFM measurements and indentation into materials with a known Young's modulus, respectively. It was found that the indenter shape is affected by the crystallographic orientation of the diamond crystal. For low depths, both investigated indenters are flatter (larger radius) than stated by the supplier. For greater depths, indenter A reaches the nominal value, and the indenter $\mathrm{B}$ has a slightly larger radius. The effective radius measured by indentation into JRQ steel and hardness etalon $487 \mathrm{HV}$ is lower than the actual radii, which is caused by the surface irregularities (for lower depths) and materials deformation characteristics (for greater depths).

Determined representative stress vs. representative strain curves of JRQ steel and hardness etalon $487 \mathrm{HV}$ are affected by the used radius (nominal or effective). To obtain indenter-independent results, effective radii determined for a given material should be used.

\section{Acknowledgment}

Support from Czech Science Foundation (project no. GB14-36566G) and Czech Technical University in Prague (project no. SGS16/172/OHK4/2T/14) is gratefully acknowledged.

\section{REFERENCES}

${ }^{1}$ K. L. Johnson, Contact mechanics, $1^{\text {st }}$ ed., Cambridge University Press, Cambridge 1985, 452

${ }^{2}$ Y. J. Park, G. M. Pharr, Nanoindentation with spherical indenters: finite element studies of deformation in the elastic-plastic transition regime, Thin Solid Films, 447-448 (2004), doi:10.1016/S00406090(03)01102-7

${ }^{3}$ D. Tabor, The Hardness of Metals, $1^{\text {st }}$ ed., Oxford University Press, London 1951, 175

${ }^{4}$ B. Taljat, T. Zacharia, F. Kosel, New analytical procedure to determine stress-strain curve from spherical indentation data, Int. J. Solids. Struct., 35 (1998) 33, doi:10.1016/S0020-7683(97)00249-7

5 J. S. Field, M. V. Swain, A simple predictive model for spherical indentation, J. Mater. Res., 8 (1993) 2, doi:10.1557/JMR.1993.0297

${ }^{6}$ K. Herrmann, N. M. Jennett, W. Wegener, J. Meneve, K. Hasche, R. Seemann, Progress in determination of the area function of indenters used for nanoindentation, Thin Solid Films, 377-378 (2000), doi:10.1016/S0040-6090(00)01367-5

${ }^{7}$ P. Haušild, A. Materna, J. Nohava, On the identification of stressstrain relation by instrumented indentation with spherical indenter, Mater. Des., 37 (2012), doi:10.1016/j.matdes.2012.01.025

${ }^{8}$ S. Sagadevan, P. Murugasen, Novel analysis on the influence of tip radius and shape of the nanoindenter on the hardness of materials, Proc. Mat. Sci., 6 (2014), doi:10.1016/j.mspro.2014.07.218

${ }^{9}$ K.-D. Bouzakis, M. Pappa, G. Maliaris, N. Michailidis, Fast determination of parameters describing manufacturing imperfections and operation wear of nanoindenter tip, Surf. Coat. Technol., 215 (2013), doi:10.1016/j.surfcoat.2012.09.061

${ }^{10}$ W. J. Zong, D. Wu, Z. Q. Li, Strength dependent design method for the crystal orientation of diamond Berkovich indenter, Mater. Des. 89 (2016), doi:10.1016/j.matdes.2015.10.062

${ }^{11}$ W.C. Oliver, G.M. Pharr, An improved technique for determining hardness and elastic modulus using load and displacement sensing indentation experiments, J. Mater. Res., 7 (1992) 6, doi:10.1557/ JMR.1992.1564

${ }^{12}$ ISO 14577:2002(E) - Metallic Materials - Instrumented indentation test for hardness and material parameters, Geneve

${ }^{13}$ J. Čech, P. Haušild, O. Kovář́k, M. Škereň, Effect of actual indenter shape on the results of spherical nanoindentation, Def. Diff. Forum., 368 (2016), doi:10.4028/www.scientific.net/DDF.368.25

${ }^{14}$ K. R. Gadelrab, F. A. Bonilla, M. Chiesa, Densification of fused silica under nanoindentation, J. Non.-Cryst. Solids, 358 (2012) 2, doi:10.1016/j.jnoncrysol.2011.10.011

${ }^{15}$ A. Bolshakov, G. M. Pharr, Influences of pileup on the measurement of mechanical properties by load and depth sensing indentation techniques, J. Mater. Res., 13 (1998) 4, doi:10.1557/JMR.1998.0146 